\title{
PELATIHAN KELOMPOK USAHA INDUSTRI KERAJINAN BAMBU RUKUN MAKMUR DI DESA PANCA TUNGGAL KECAMATAN SUNGAI LILIN KABUPATEN MUSI BANYU ASIN PROVINSI SUMATERA SELATAN
}

\author{
Husni Mubarat'1), Aji Windu Viatra'), Mukhsin Patriansah'1) \\ 1)Program Studi Desain Komunikasi Visual, Fakultas Ilmu Pemerintahan dan Budaya, Universitas Indo Global Mandiri, \\ Palembang, Sumatera Selatan, Indonesia \\ Corresponding author : Husni Mubarat \\ E-mail : husni_dkv@uigm.ac.id
}

Diterima 17 November 2021, Direvisi 02 Desember 2021, Disetujui 02 Desember 2021

\begin{abstract}
ABSTRAK
Pengabdian kepada Masyarakat dengan tema Pelatihan Kelompok Usaha Industri Kerajinan Bambu Rukun Makmur ini dilaksanakan di Desa Panca Tunggal Kecamatan Sungai Lilin Kabupaten Musi Banyu Asin. Kegiatan ini berlangsung selama dua hari, yaitu dari tanggal 1-2 November 2021. Adapun tujuan kegiatan ini adalah memberikan keterampilan dasar bagi pemula dalam membuat kerajinan bambu, memberikan pengetahuan tentang pemakaian alat-alat mesin dan manual, memberikan pengetahuan tentang pengembangan desain produk bagi pengrajin yang sudah melewati tahap pemula. Metode kegiatan pelatihan ini menggunakan metode ceramah dalam bentuk penyampaian materi teori, praktik, dan evaluasi. Adapun hasil pelatihan selama kegiatan ini yakni pengetahuan secara teoritik dan praktek. Secara teori peserta mendapatkan pengetahuan tentang industri kerajinan dan tahap-tahap pengembangan desain. Secara praktek kegiatan ini menghasilkan produk kreasi lampu hias dari bahan bambu dan stand handphone yang dilengkapi dengan tempat pena. Pelatihan ini memberikan peningkatan dan pengembangan dari jenis produk, yang mana sebelumnya mitra hanya menghasilkan produk seperti miniatur kapal. Kegiatan ini sangat efektif dalam meningkatkan keterampilan mitra, yang mana mitra dapat mempraktikkan secara langsung dalam pembuatan produk kerajinan bambu.
\end{abstract}

Kata kunci: industri; kerajinan; bambu; panca tunggal.

\begin{abstract}
Community Service with the theme of the Rukun Makmur Bamboo Craft Industry Business Group Training was held in Panca Tunggal Village, Sungai Lilin District, Musi Banyu Asin Regency. This activity lasts for two days, from November 1-2, 2021. The purpose of this activity is to provide basic skills for beginners in making bamboo crafts, provide knowledge about the use of machine tools and manuals, provide knowledge about product design development for craftsmen who have passed the beginner stage. The method of this training activity uses the lecture method in the form of delivering theoretical, practical, and evaluation material. The results of the training during this activity are theoretical and practical knowledge. In theory, participants gain knowledge about the craft industry and the stages of design development. Practically, this activity produces decorative lighting products from bamboo and a mobile phone stand equipped with a pen holder. This training provides improvement and development of product types, where previously partners only produced products such as miniature ships. This activity is very effective in improving the skills of partners, which partners can practice directly in the manufacture of bamboo handicraft products.
\end{abstract}

Keywords: industry; craft; bamboo; panca tunggal.

\section{PENDAHULUAN}

Seni kerajinan merupakan salah satu sektor industri kreatif yang memiliki potensii untuk menunjang perekonomian masyarakarat terutama di pedesaan. Pembangunan ekonomi merupakan suatu proses yang mana masyarakat dapat menciptakan suatu lingkungan yang mempengaruhi hasil-hasil indikator ekonomi seperti kenaikan kesempatan kerja, peningkatan pendapatan, dan perbaikan taraf hidup. (Juhari et al., 2020). Setiap desa di Indonesia memiliki potensinya masing-masing, baik budaya maupun alamnya yang dapat dikembangkan menjadi unit usaha dan keterampilan bagi masyarakatnya. Desa Panca Tunggal Kecematan Sungai Lilin Kabupaten Musi Banyu Asin Sumatera Selatan adalah salah satu desa yang memiliki sumber daya alam yang dapat diolah menjadi produk-produk 
kerajinan, salah satunya adalah kerajinan bambu.

Tumbuhan bambu salah satu Sumber Daya Alam yang dimiliki oleh Desa Panca Tunggal. Sejauh ini Desa Panca Tunggal hanya memanfaatkan untuk kebutuhan pembuatan pagar rumah dan kebutuhan pertanian. Selain itu, ada juga warga yang memenfaatkan bambu untuk mebuat produk kerajinan, seperti miniatur kapal dan mobil. Akan tetapi sangat disayangkan masih sangat sedikit warganya yang mengolah bambu untuk dijadikan sebagai bahan baku industri kerajinan. Salah satu faktornya adalah kurangnya bekal dan keterampilan yang dimiliki oleh masyarakat. Selain dari faktor tersebut, kurangnya minat bagi masyarakat untuk mengolah sumber daya alam seperti bambu juga terkendala dari aspek promosi dan pemasaran produk. Salah satu penyebabnya adalah kurangnya pengetahuan terhadap tekhnologi sebagai media promosi dan pemasaran produk di era digital saat ini. Oleh karena itu, melalui Pelatihan Kelompok Usaha Industri Kerajinan ini diharapkan dapat meningkatkan keterampilan masyarakat Desa Panca Tunggal, khususnya dalam mengolah kerajinan bambu. Kegiatan pelatihan ini dilkasanakan dari tanggal 1 sampai 12 November 2021.

Menurut Lewin (1951) dan Cartwright (1968) kelompok adalah kumpulan manusia, dua orang atau lebih yang menunjukkan saling ketergantungan dengan pola interaksi yang nyata. Slamet (2001) memberikan pengertian yang lebih tegas terhadap kelompok yang mengatakan dua atau lebih orang yang berhimpun atas dasar adanya kesamaan, berinteraksi melalui pola/struktur tertentu guna mencapai tujuan bersama, dan dalam kurun waktu yang relatif panjang. Kesamaankesamaan tersebut harus menjadi landasan utama sehingga kelompok dapat berfungsi dengan baik (Tampubolon et al., 2006). Adapun kelompok usaha industri kerajinan di Desa Panca Tunggal ini tergolong kelompok masyarakat ekonomi menengah ke bawah, yang mana penghasilan kesehariannya hanya sebatas mencukupi untuk memenuhi kehidupan sehari-hari. Kehidupan masyarakat tidak terlepas dari kelompok, termasuk kelompok miskin.

Kegiatan pelatihan bagi kelompok usaha industri kerajinan ini tidak terlepas dari peran Dinas Pemberdayaan Masyarakat dan Desa (DPMD) Kabupaten Musi Banyu Asin Provinsi Sumatera Selatan yakni sebagai salah satu program pemberdayaan masyarakat yang bertujuan untuk memberikan keterampilan dan kreativitas bagi masyarakat dengan tujuan untuk menunjang perekonomian masyarakat desa. Selain dibekali dengan keterampilan dan kreativitas masyarakat juga dihibahkan beberapa peralatan mesin agar dapat mempermudah kegiatan produksi dan meningkatkan kualitas serta kuantitas sehingga kegiatan produksi dapat berjalan secara berkelanjutan. Melaksanakan suatu kegiatan pemberdayaan masyarakat pasti memiliki tujuan-tujuan yang akan dicapai. Tujuan disini berfungsi sebagai pendorong agar kegiatan yang dilaksanakan dapat tercapai dan membawa manfaat bagi lingkungan, masyarakat sekitar, maupun anggota atau tenaga kerja yang ada di dalam kegiatan tersebut (Mintarti, S.U.W., Handayani, S., Megasari, R., 2018).

Dari 10 orang jumlah peserta pelatihan, tidak semua peserta memiliki keterampilan mengolah kerajinan bambu, hampir $80 \%$ perserta belum pernah mengolah kerajinan bambu. Oleh karena itu, pelatihan yang dilaksanakan ini adalah pelatihan dasar sebagai bekal awal bagi masyarakat untuk dapat memanfaatkan potensi bambu sebagai bahan baku untuk membuat produk kerajinan. Adapun jenis produk yang dibuat di antaranya adalah lampu hias dan stand handphone.

Dalam proses pelatihan kelompok kerajinan industri ini, peserta pelatihan diajarkan teknik-teknik dasar mengolah bambu, seperti teknik sambungan, teknik pahat, dan teknik finishing. Selain pelatihan teknik dasar, masyarakat juga dibelakali dengan teknik pengemasan sebagai penunjang daya tarik bagi pembeli, di samping itu tentunya hal ini berfungsi untuk melindungii produk ketika nantiya produk tersebut dipesan ataupun dijual secara online.

Di samping itu, dalam kegiatan pelatihan kerajinan kelompok industri di Desa Panca Tunggal peserta pelatihan juga diberikan pengetahuan tentang bagai mana memilih bahan baku bambu yang baik dan bagaimana pula mengolah bahan baku tersebut agar awet ataupun tidak bubuk pada saat bambu tersebut menjadi sebuah produk. Sistem pengawetan bambu yang disampaikan pada kegiatan pelatihan tersebut yaitu sistem pengawetan tradisional yang mana bambuyang sudah ditebang dilakukan proses perendaman selama lebh kuran 7 hari. Setelah direndam bambu tersebut diangkat kemudian dijemur di tempattempat yang tidak terkena matahari secara langsung. 


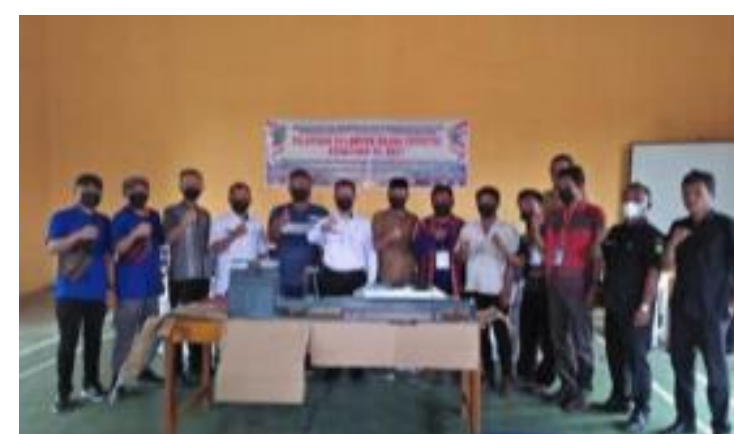

Gambar 1. Foto bersama peserta pelatihan dan Kepala Desa Panca Tunggal dalam kegiatan penyerahan alat mesin dan manual untuk pelatihan, seperti bor tuner, mesin bubut kayu, dan pahat ukir kayu.

(Sumber: Siddiq, 2021)

Secara garis besarnya, pelatihan ini bertujuan untuk memberikan keterampilan dasar bagi masyarakat Desa Panca Tunggal, khususnya keterampilan kerajinan bambu. Melalui pelatihan ini diharapakan dapat memberi kebermanfaatan bagi masyarakat sehingga nantinya dapat menunjang perekonomian keluarga. Dari 10 orang jumlah peserta yang ikut serta dalam pelatihan ini dapat menjadi promotor untuk mengajak masyarakat yang lainnya mengolah bahan baku bambu, sehingga nantinya diharapakan Desa Panca Tunggal dapat menjadi sentra kerajinan bambu di Kecamatan Sungai Lilin Kabupaten Musi Banyu Asin, dengan demikian ketrampilan ini diharapakan dapat meningkatkan kesejahteraan dan mengurangi pengangguran bagi masyarakat.

\section{METODE}

Kelompok Kerajinan Rukun Makmur Desa Panca Tunggal sudah berdiri dari tahun 2018. Sebelumnya kelompok ini sudah pernah mendapatkan pelatihan pada tahun 2018, namun setelah pelatihan tersebut Indonesia dilanda musiabah Pandemi Covid 19, sehingga kelompok Pengrajin Rukun Makmur Desa Panca Tunggal menjadi vakum lebih kurang selama 2 tahun. Di era new normal saat ini kegiatan-kegiatan produktif masyarakat Desa Panca Tunggal sudah mulai berangsur normal kembali, sehingga pelatihan ini dapat terlaksana sesuai jadwalnya. Adapun jumlah peserta yang ikut dalam pelatihan kerajinan bambu ini sebanyak 10 orang. Kegiatan ini dilaksanakan selama 2 hari, dari tanggal 1-2 November 2021.

Dalam pelatihan dasar bagi kelompok usaha industry kerajinan Rukun Makmur, tentunya sangat dibutuhkan metode yang tepat dan efektif, agar masyarakat dapat dengan mudah untuk memahami apa yang disampaiakan pada saat pelatihan. Metode dapat dipahami sebagai cara, teknik, strategi maupun sistem dan prosedur yang ditempuh untuk mencapai suatu tujuan (Mubarat et al., 2019).

Dalam kegiatan pelatihan ini ada beberapa metode yang digunakan, di antaranya adalah:

1. Survei dan wawancara, metode ini merupaka proses untuk mengumpulkan data-data yang berkaitan dengan pelatihan, seperti data mengenai tingkat keterampilan peserta. Dari data ini diketahui sebanyak 2 orang peserta telah mengikuti pelatihan sebeumnya, sehingga memiliki keterampilan dasar dalam membuat kerajinan bambu, khususnya miniatur kapal. Sedangkan untuk 7 orang peserta lainnya masih dalam tahap keterampilan dasar. Kegiatan survei juga dilakukan untuk mengetahui jenis-jenis bambu yang tersedia di Desa Panca Tunggal tersebut. Adapun jenis bambu yang tersedia di Desa tersebut adalah bambu apus.

2. Metode ceramah, yaitu penyampaian materi pelatihan secara presentasi yang memuat tentang pengetahuan yang bersifat teoritik seperti pengenalan jenis bambu, proses pengawetan, teknik-teknik pembuatan desain, serta memberikan pemahaman industri kerajinan sebagai salah satu sektor industri kreatif. Melalui metode ini tentunya diharapkan peserta pelatihan memiliki bekal pengetahuan dan wawasan sehingga dapat memotivasi untuk mengolah potensi bambu sebagai bahan baku industri kerajinan untuk penunjang ekonomi keluarga.

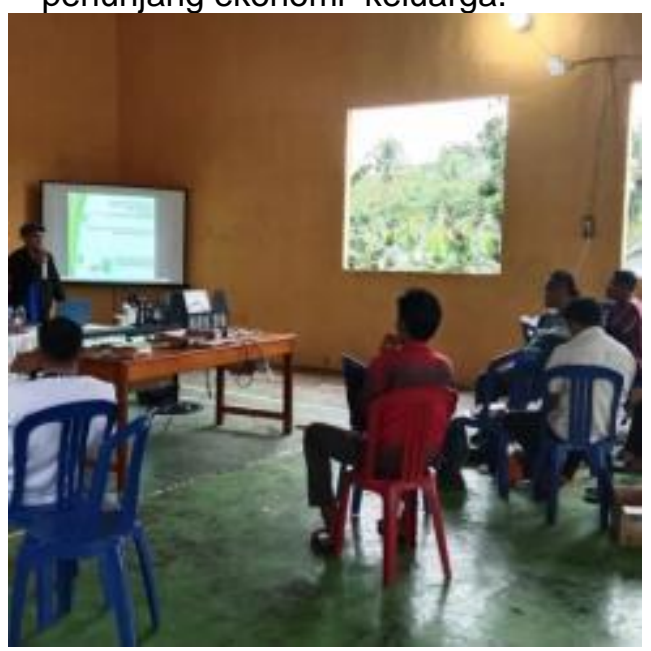

Gambar 2. Pemaparan materi praktik pelatihan kerajinan bambu di Desa Panca Tunggal.

3. Metode praktik dan demonstrasi, yaitu penyampaian materi dengan cara 
mempraktekkan pembuatan produk kerajinan bambu secara langsung seperti pembuatan desain dan pola kerja, cara menerapkan teknik pahat, dan teknik finishing.

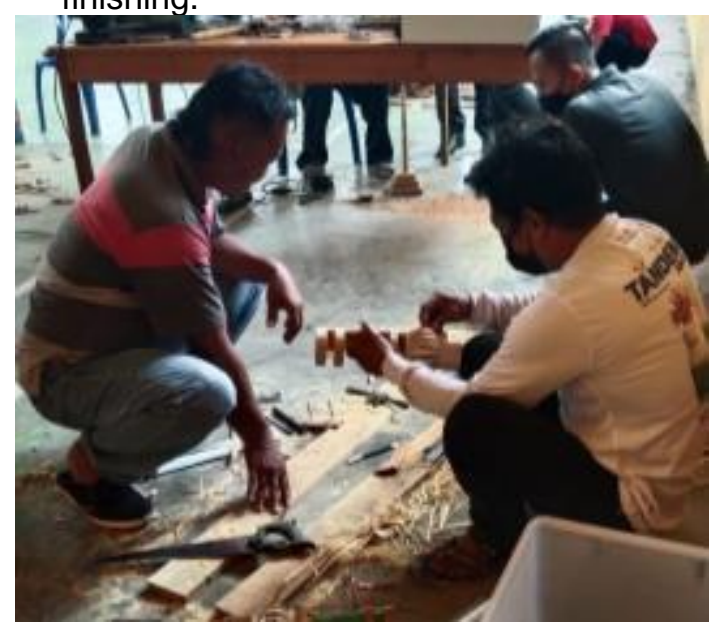

Gambar 3. Pemaparan materi praktek pelatihan kerajinan bambu di Desa Panca Tunggal.

4. Metode Evaluasi, yaitu kegiatan untuk mengukur sejauh mana peserta pelatihan dapat memahami materi yang disampaikan oleh narasumber, baik secara teoritik maupun praktek. Melalui metode ini, diharapkan dapat menarik kesimpulan seperti apa saja kendala dan permasalahan yang menghambat selama pelatihan sehingga permasalahan tersebut dapat dicarikan solusinya untuk tahapan yang berikutnya sehingga kegiatan produksi kerajinan bambu dpat terlaksana secara kontiniu.

\section{HASIL DAN PEMBAHASAN}

Sinergitas sebagai Upaya Pemberdayaan Kelompok Usaha Industri Kerajinan

Dalam upaya untuk

mengimplementasikan keterampilan dan kreativitas bagi kelompok usaha industri kerajinan di Desa Panca Tunggal diperlukan kerja sama yang baik, yakni diperlukannya sinergi antara kelompok usaha industri, pemerintah, dan kaum intelektual. Kelompok usaha industri sebagai pelaku usaha yang menghasilkan produk kerajinan, komponen pemerintah sebagai kelompok yang membantu pemasaran dan pendampingan, sedangkan kelompok intelektual berperan sebagai tim riset dan narasumber dalam memberikan solusi untuk peningkatan dan pengembangan produkproduk kerajinan. Menurut Susila (2016) dalam (Wolok et al., 2020) mengungkapkan bahwa Sinergi Pemeritah dan Perguruan Tinggi serta masyarakat sangat diperlukan dalam upaya pemberdayaan untuk meningkatkan kesejahteraan. Dengan kerjasama ketiga komponen tersebut, tentunya proses produksi industry kerajinan dapat berjalan dengan baik serta upaya untuk meningkatkan kualitas dan kuantitas produk dapat dicapai sesuai dengan target dan standarnya.

Sinergitas antara komponen di atas tersebut diharapkan juga dapat meningkatkan produktivitas dari masyarakat, mengingat sebahagian dari peserta pelatihan masih berusia produktif, yaitu umur 30 th -45 Th. Selain itu juga tersedianya bahan bambu sebagai bahan utama dan tersedianya alat mesin dan manual yang dapat dimanfatkan untuk menunjang proses produksi. Payaman (1998) dalam (Adnan, 2008) mengungkapkan bahwa, Secara teoritis produktivitas tenaga kerja dipengaruhi oleh faktor-faktor, pertama; kualitas dan kemampuan fisik tenaga kerja, dipengaruhi oleh pendidikan, training, motivasi kerja, etika kerja, mental, kemampuan fisik tenaga kerja. Kedua sarana pendukung meliputi lingkungan kerja dan kesejahteraan pekerja. Ketiga, supra sarana pendukung berupa kebijakan.

\section{Indikator Kebrhasilan Kegiatan}

Indikator keberhasilan dalam sebuah kegiatan pengabdian kepada masyarakat, merupakan salah satu aspek yang cukup penting untuk dijadikan sebagai tolak ukur sejauhmana peserta mampu menerapkan materi yang disampaikan oleh narasumber, baik secara teknisnya maupun secara konseptual. Pada pelatihan kelompok industri kerajinan di Desa Panca Tunggal, khususnya kerajinan bambu dapat diuraikan sebagai berikut:

1. Peserta kerajinan bambu sudah dapat mengimplemnetasikan teknik dan proses pembuatan kerajinan lampu hias dan stand Handphone dari bahan bambu. Hal ini dikarenakan beberapa peserta sebelumnya sudah memiliki keterampilan untuk mengolah bambu menjadi miniatur kapal.

2. Peserta pelatihan sudah dapat menghasilkan produk lampu hias dari bahan baku bambu dengan kualitas yang sudah dapat dipasarkan.

3. Peserta sudah dapat mengembangkan desain-desain produk yang sebelumnya menjadi bentuk produk yang baru, sehingga produk yang dihasilkan memiliki variasi.

4. Peserta sudah mengerti tentang prinsip-prinsip dalam pembuatan produk kerajinan bambu, seperti nilai estetika, pengembangan fungsi produk, dan pengembangan desain produk. 
Proses dan Tahapan Pengerjaan

\section{Persiapan Desain}

Desain merupakan salah satu bagian penting yang harus dipersiapkan sebelum mengerjakan sebuah produk kerajinan bambu. Desain berfungsi sebagai pedoman dalam proses pembuatan kerajinan bambu, baik dari bentuk produk yang akan dibuat, ukuran, maupun fungsi produk itu sendiri. Oleh karena itu, sangat penting sekali untuk memberikan pemahaman dasar kepada peserta pelatihan dalam pembuatan desain.

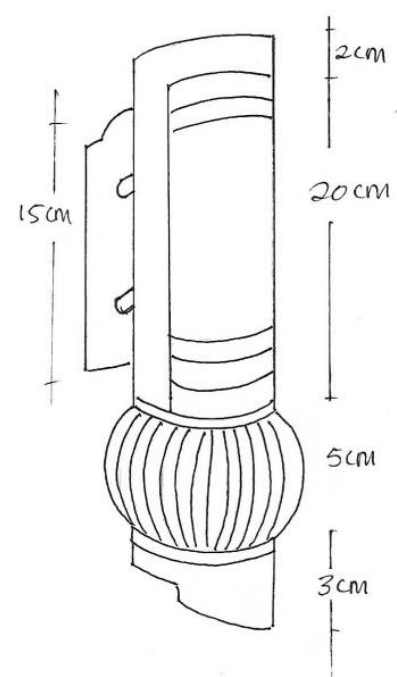

Gambar 4. Desain kerajinan lampu hias dari bahan bambu

\section{Persiapan Bahan}

Adapun bahan-bahan yang dipersiapkan dalam pelatihan kerajinan bambu di desa Panca Tunggal ini di antaranya terdiri dari bahan pokok dan bahan penunjang. Bahan pokok berupa bambu sebagai bahan utama, adapun bambu yang digunakan adalah bambu apus dan ulung. Kedua jeis bambu tersebut dirasakan sangat cocok untuk bahan dasar dalam pelatihan tersebut. Adapun bahan penunjang yang dibutuhkan yaitu lem, kabel listrik, bola lampu, piting, seklar dan colokan lampu.

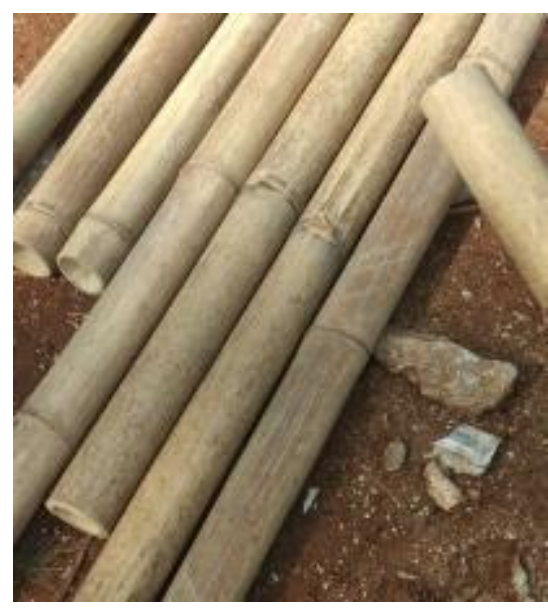

Gambar 5. Bahan jenis bambu apus sebagai bahan utama dalam pelatihan kerajinan bambu

3. Persiapan alat.

Alat merupakan bagian yang tidak kalah pentingnya dalam proses pembuatan kerajinan bambu, sebab alat-alat yang dipersiapkan akan menentukan hasil dari produk tersebut, jika alat-alatnya bagus dan lengkap maka proses pembuatan produkpun akan dapat berjalan dengan lancar. Selain kelengkapan alat, peserta pelatihan juga diberi pemahamana bahwa alat-alat yang dipersiapkan juga dibutuhkan alat-alat yang tajam agar dalam proses pengerjaan kerajinan bambu dapat menghasilkan produk yang baik dan berkualitas. Dalam proses pengerjaan kerajinan bambu sendiri, pada dasarnya banyak menggunakan alat-alat manual, seperti gergaji potong, ketam raut, pisau raut, dan seperangkat alat ukiran kayu.

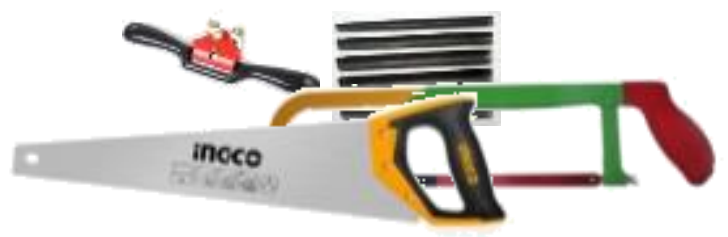

Gambar 5. Jenis-jenis alat yang digunakan pada pelatihan kerajinan lampu hias dari bambu.

\section{Kegiatan Pelatihan}

Adapun tahapan kegiatan pelatihan adalah:

a. Memotong bahan bambu ukuran T: $30 \mathrm{~cm} \times$ D: $9 \mathrm{~cm}$. bambu dipotong dengan menyisakan ruas sekitar 7 $\mathrm{cm}$. memotong bambu dapat dilakukan dengan gergaji manual. Sebelum memotong bambu pastisak dulu kalau gergaji benarbenar sudah tajam. 


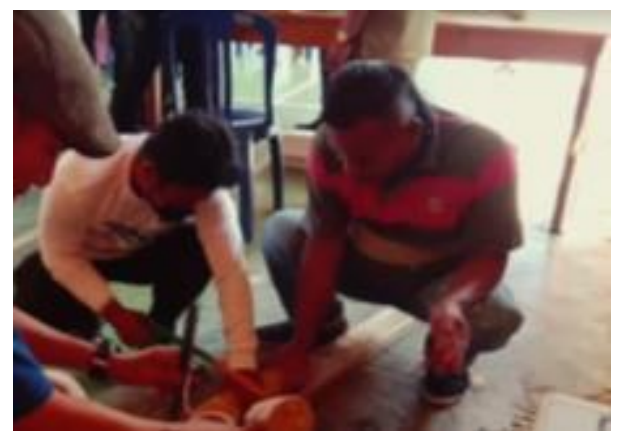

Gambar 6. Proses pemotongan bahan bambu sesuai dengan ukuran yang telah ditentunkan

b. Melepaskan kulit atau sembilu bambu dengan alat ketam raut atau pahat ukir kayu. Pada tahap ini dapat juga dibantu dengan menggunakan pisau raut. Sebelum menyerut kulit bambu ada baiknya mata serutan dicek, baik ketajamannya maupun ketebalan mata serutannya. Hal ini bertujuan agar bambu menjadi lebih halus. Jika yang digunakan jenis bambu hitam, maka tidak perlu dilepaskan sembilunya.

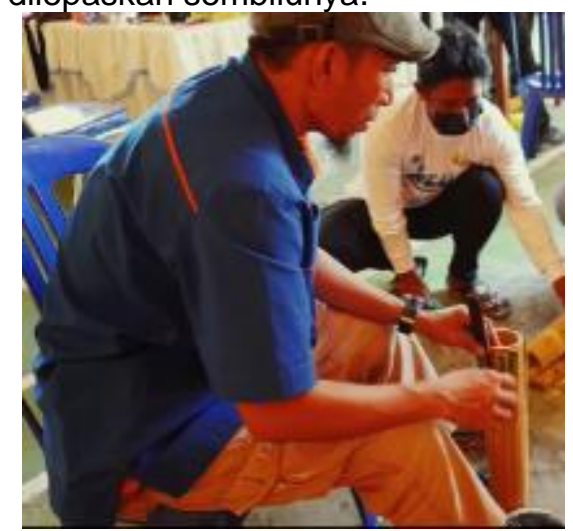

Gambar 7. Proses melepaskan kulit bambu dengan alat pahat ukiran kayu

c. Memotong bambu sesuai dengan polanya atau desainnya. Tahap ini merupakan pembentukan lubang pada bambu yang nantinya berfungsi untuk cahaya lampu.

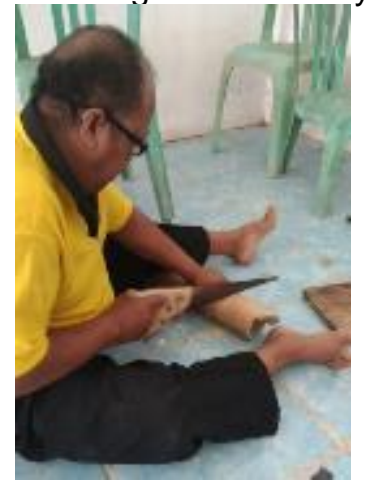

Gambar 8. Proses pemotongan bambu sesuai dengan pola yang telah ditentukan d. Tahap perakitan lengkungan potongan bambu. Tahap ini dilakukan dengan teknik dilem. Adapun lem yang digunakan adalah lem korea.

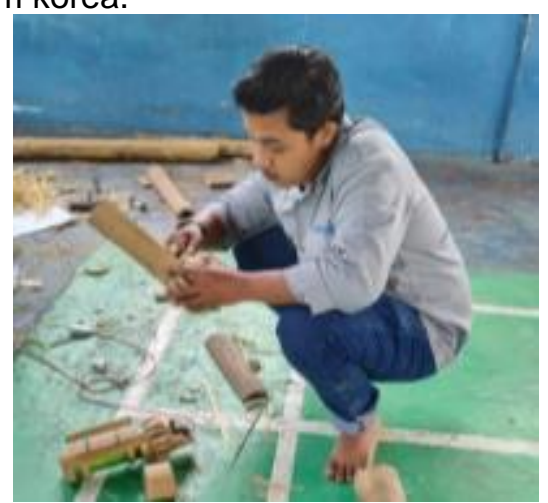

Gambar 9. Proses pemotongan bambu sesuai dengan pola yang telah ditentukan

e. Tahap Finishing, finishing menggunakan cat jenis impra, pada bambu hitam jenis impra dapat menggunakan cleaer gloss/ doff. Finishing dapat dilakukan dengan alat kuas maupun kompresor.

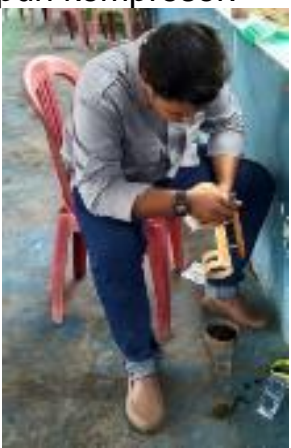

Gambar 10. Proses Finishing dengan menggunakan alat kuas.

\section{Hasil Produk Pelatihan}

Adapun produk kerajinan bambu yang dihasilkan selama pelatihan di Desa Panca Tunggal adalah sebagai berikut:

1. Produk lampu Hias

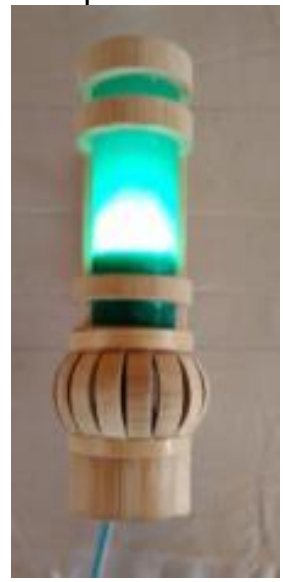

Gambar 4. Hasil pelatihan produk kerajinan bambu lampu hias

(Sumber: Husni Mubarat, 2021) 
Produk lampu hias yang dihasilkan pada kegiatan pelatihan kelompok usaha industri kerajinan di Desa Panca Tunggal, tidak hanya berfungsi untuk menambah penerangan dalam ruangan, tetapi juga berfungsi sebagai penghias dalam ruangan. Lampu hias dari bambu ini dapat diletakkan di rungan tidur, sebagai hiasan ruang tamu, dan dapat pula difungsikan lampu hias teras rumah.

Adapun tekhnik yang digunakan dalam proses pembuatan lampu hias ini yakni teknik manual sambung lem, teknik pahat, dan potong, di samping itu pelatihan kerajinan bambu produk lampu hias ini juga memperkenalkan cara pengoperasian mesin sebagai peralatan untuk meningkatkan kualitas dan kuantitas produk. Di samping dapat dijadikan lampu hias di rumah sendiri, kerajinan lampu hias dari bambu tersebut juga memiliki nilai jual. Selain bentuknya yang unik, nilai tambah dari produk tersebut yakni bahan baku bambu yang digunakan yang bersifat alami. Di samping itu bahan baku yang tersedia juga cukup banyak di Desa Panca Tunggal sehingga sangat memungkinkan bagii kelompok industri kerajinan untuk membuat kerajinan bamboo.

Untuk desainnya sendiri, tentunya produk yang dihasilkan selama pelatihan masih dalam bentuk yang sederhana, mengingat pelatihan bambu, khususnya produk lampu hias, ini merupakan pelatihan tahap pertama. Diharapkan ke dapnnya kelompok industri kerajinan Desa Panca Tungga dapat mengembang produk-produk kerajinan bamboo lampu hias, baik dari aspek desainnya maupun fungsinya, seperti lampu meja, lampu lantai dan lampu gantung.

2. Produk tempat Pena dan Stand Handphone

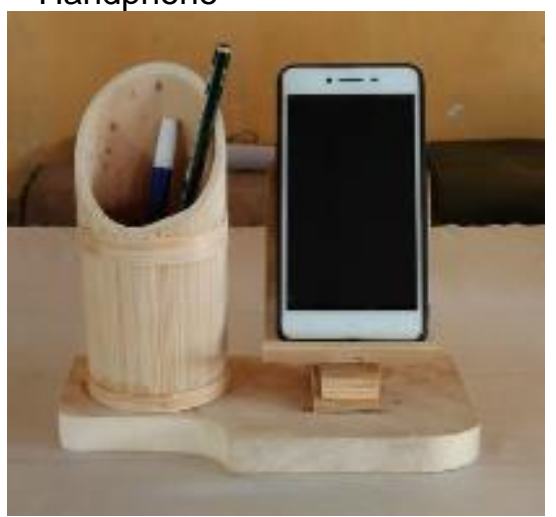

Gambar 5. Hasil pelatihan produk kerajinan bambu Stand HP dan tempat pena

(Sumber: Husni Mubarat, 2021)

Stand HP dan tempat menggunakan bahan baku utama bambu yang dikombinasikan dengan kayu pada bagian alasnya. Produk tersebut dapat digunakan di meja perkantoran dan meja belajar. Produk ini merupakan salah satu yang dihasilkan dari pelatihan bambu di Desa Panca Tunggal. Bila diamati dari aspek bentuknya, memang belum tergarap secara maksimal, masih ada beberapa kekurangannya seperti kerapian, desainnya dan teknik pengerjaannya. Akan tetapi sebagai tahap awal, produk tersebut sudah dapat dikatakan cukup lumayan dan tentunya produk tersebut dapat dikembangkan lagi, terutama dari aspek desainnya.

Hasil pelatihan produk HP dan tempat pena menggunakan teknik pengerjaan yaitu teknik sambung pen dan teknik potong scroll saw. Diharapkan peserta tidak hanya dapat menguasai teknik pengerjaanya dengan baik, tetapi diharapakan juga dapat mengoperasi peralatan mesin. Dengan demikian dalam proses produksi untuk ke depannya dapat meningkatkan kualitas dan kuantitas dari produk sehingga dapat memmenuhi permintaan konsumen.

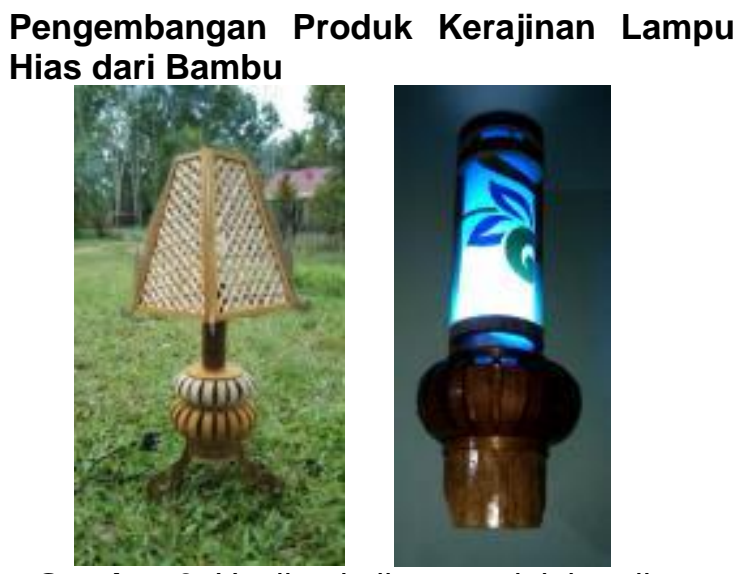

Gambar 6. Hasil pelatihan produk kerajinan bambu lampu hias

(Sumber: Husni Mubarat, 2021)

\section{SIMPULAN DAN SARAN}

Kegiatan pelatihan Kelompok Usaha Indusrti Kerajin di Desa Panca Tunggal Kec. Sungai Lilin Kabupaten Musi Banyu Asin terlaksana sesuai dengan jadwal yang sudah ditentukan. Dari kegiatan yang telah dilaksanakan dapat disimpulkan; pertama peserta mengikuti kegiatan pelatihan dari awal hingga akhir dengan antusias, kedua, peserta sudah dapat membuat produk lampu hias dari bahan bambu, ketiga, peserta sudah dapat mengimplementasikan teknik-teknik pembuatan lampu hias dari bambu, keempat, peserta sudah dapat mengembangkan desain produk lampu hias dari bambu. Adapun saran yang dapat disampaikan yakni, pertama, bagi peserta ada baiknya sebelum proses produksi dimulai terlebih dahulu persiapkan bahan dan 
peralatan kerja, khususnya untuk bahan baku, bambu sebaiknya dipilih yang sudah tua dan kering. Ada baiknya lagi bahan-bahan bambu terlebih dahulu direndam selama 7 hari dan dijemur di tempat yang tidak terkena matahari secara langsung, kedua bagi aparatur pemerintahan Desa, ada baiknya menunjukkan seorang operator yang secara khusus sebagai orang yang bertanggung jawab untuk promosi dan pemasaran dari pada produk-produk kelompok usaha industri kerajinan, ketiga bagi pemerintahan Dinas Pemberdayaan Masyarakat dan Desa, ada baiknya pelaksanaan kegiatan ini ditambahkan durasi waktunya minimal lima hari, sehingga kelompok industri kerajinan benar-benar dapat memahami materi yang disampaikan, dan tentunya kegiatan ini sebaik mungkin dilaksanakan secara berkala agar pemberdayaan kelompok industri kerajinan dapat berkembang dengan baik.

\section{UCAPAN TERIMAKASIH}

Ucapan terima kasih kami sampaikan kepada peserta pelatihan atas apresiasi dan antusiasnya dalam mengikuti pelatihan tersebut. Kepada Kepala Desa Panca Tunggal dan jajaranya kami ucapakan terima kasih atas sambutan dan apresiasi kepada kami sebagai narasumber. Ucapan terima kasih kepada Dinas Pemberdayaan Masyarakat dan Desa (DPMD) Kabupaten Musi Banyu Asin yang telah mempercayakan kami sebagai nara sumber dalam kegiatan pelatihan ini. Tidak lupa kami ucapkan kepada Universitas Indo Global Mandiri (UIGM) Palembang yang telah memberi izin dan dukungannya kepada kami untuk melaksanakan kegitan Tridarma Perguruan Tinggi ini, semoga kegiatan ini dapat dilakukan secara berkala.

\section{DAFTAR RUJUKAN}

Adnan, N. (2008). Kinerja Industri Kerajinan Ukir di Kota Palembang. Jurnal Ekonomi Pembangunan, 6(2), 70-84.

Juhari, J., Widayat, R. M., \& Mujiyana, M. (2020). Pengembangan Kerajinan Anyaman Palitan, Di Dusun Nglengkong, Desa Giripurwo, Kecamatan Girimulyo, Kabupaten Kulon Progo. SELAPARANG Jurnal Pengabdian Masyarakat Berkemajuan, 4(1), 491. https://doi.org/10.31764/jpmb.v4i1.2808

Mintarti, S.U.W., Handayani, S., Megasari, R., dan P. R. D. (2018). Pemberdayaan Home Industry Kerajinan. 5.

Mubarat, H., Chanaldy, R. S., \& Yanto, D. (2019). Pengembangan Produk Lukis Lakuer Menjadi Produk Kerajinan. Batoboh, 4(2), https://doi.org/10.26887/bt.v4i2.901

Tampubolon, J., Sugihen, B. G., Samet, M., Susanto, D., \& Sumardjo, S. (2006). PEMBERDAYAAN MASYARAKAT MELALUI PENDEKATAN KELOMPOK (Kasus Pemberdayaan Masyarakat Miskin melalui Pendekatan Kelompok Usaha Bersama (KUBE). Jurnal Penyuluhan, 2(2). https://doi.org/10.25015/penyuluhan.v2i2. 2122

Wolok, T., Sulila, I., \& Dungga, W. A. (2020). Implementasi PPDM Desa lluta Pesisir Danau Limboto Melalui Manajemen Keuangan dan Standarisasi Ragam Produk Eceng Gondok sebagai Produk Unggulan. E-Dimas: Jurnal Pengabdian Kepada Masyarakat, 11(2), 240-247. https://doi.org/10.26877/edimas.v11i2.5625 